\title{
Meningkatkan Self Esteem dengan Menggunakan Pendekatan Rational Emotive Behavior Therapy pada Peserta Didik Kelas VIII Di SMP Muhammadiyah Jati Agung Lampung Selatan Tahun Pelajaran 2015/2016
}

\author{
Muhammad Ikbal, Nurjannah \\ Dosen Fakultas Tarbiyah dan Keguruan, IAIN Raden Intan Lampung
}

Diterima: 10 Januari 2016. Disetujui: 20 Februari 2016. Dipublikasikan: Mei 2016

\begin{abstract}
Abstrak: Self esteem merupakan penilaian seseorang terhadap dirinya sendiri, baik berupa penilaian negatif maupun penilaian positif yang akhirnya menghasilkan perasaan yang membawa kepercayaan diri dalam menjalani kehidupan. Self esteem rendah menyulitkan peserta didik dalam berinteraksi social. Self esteem yang maih terdapat pada peserta didik kelas VIII di SMP Muhmmadiyah Jati Agung sehingga diperlukan sebuah upaya untuk mengatasi self esteem rendah melalui konseling individual dengan pendekatan rational emotive behavior therapy. Metode yang digunakan dalam penelitian ini adalah pre-experimental design dengan one group petest- posttest dengan sampel penelitian yang berjumlah 12 peserta didik kelas VIII di SMP Muhammadiyah Jati Agung tahun pelajaran 2015/2016 yang memiliki tingkat self esteem rendah. Berdasarkan uji wilcoxon dalam tabel 4.5, diperoleh nilai Asymp.Sig.(2-tailed) sebesar 0.002 karena nilai sig $0.002<$ 0.005 , dengan perhitungan pengujian wilcoxon diperoleh Zhitung -3.007 dan Ztabel $0.05=0.0011$, maka Zhitung $>$ Ztabel $(-3.007>0.0011)$ dengan nilai sign (2-tailed) dengan demikian berdasarkan uji wilcoxon dapat disimpulkan Ho ditolak Ha diterima, jadi dapat disimpulkan bahwa self esteem yang rendah dapat ditingkatkan dengan menggunakan pendekatan Rational Emotive Behavior Therapy.Maka, dari data tersebut dapat dilihat Ho di tolak dan Ha yang berbunyi pendekatan rational emotive behavior therapy dapat meningkatkan self esteem peserta didik kelas VIII SMP Muhmaadiyah Jati Agung Lampung Selatan tahun pelajaran 2015/2016 diterima. Saran untuk guru bimbingan konseling agar dapat menggunakan layananan individual melalui pendekatan rational emotive behavior therapy dalam meningkatkan self esteem peserta didik.
\end{abstract}

Kata Kunci: self esteem, rational emotive behavior therapy

\section{Pendahuluan}

Permasalahan yang dialami remaja seringkali dan bahkan hampir semua berasal dari dalam diri mereka sendiri. Mereka tanpa sadar menciptakan konflik yang berasal dari masalah self esteem. Remaja cenderung terlalu cepat berfikir dan menilai secara irasional akan dirinya ataupun orang lain, bahkan menyakini persepsi yang belum tentu kebenarannya. Dari situlah muncul ganguan emosional yang nantinya akan mempengaruhi dalam hubungannya dengan orang lain.

Ketidakmampuan untuk menghadapi secara positif situasi sosial dapat menyebabkan rendahnya self esteem. Remaja dengan self esteem yang tinggi selalu memandang positif setiap hal yang ada dalam diri dan kehidupannnya. Sebaliknya, remaja dengan self esteem yang rendah melihat dunia melalui fliter yang lebih negatif, dan tidak menyukai persepsi umum tentang gambaran dari segala sesuatu di sekitarnya. Hal seperti ini yang dapat mengganggu perkembangan kepribadian remaja karena perkembangan self esteem pada seseorang remaja akan menentukan keberhasilan atau kegagalan di masa depannya.

Dari hasil pra penelitian yang dilakukan di SMP Muhammadiyah Lampung Selatan, menurut inforamsi guru pembimbing dapat diketahui bahwa telah terjadi gejala-gejala self esteem yang rendah pada diri siswa tersebut. Selain melakukan wawancara dengan guru pembimbing, peneliti juga melakukan wawancara dengan peserta didik yang teridentifikasi memiliki self esteem yang rendah untuk mengetahui faktor penyebab dari rendahnya self esteem mereka.Ternyata faktor penyebab dari self esteem mereka yang rendah sangat beragam. RES pernah dipermalukan teman-temanya ketika sedang menyampaikan pendapatnya, MF dan merasa bahwa dirinya tidak lebih pintar dari teman-temanya yang lain, 
sehingga dijauhi teman-temannya, BNS dan SW menyatakan bahwa dirinya merasa minder karena kondisi fisiknya yang menurutnya tidak sesempurna teman-temanya, SP merasa sebagai orang yang tidak beruntung karena selalu gagal dalam segala hal baik yang menyangkut prestasi maupun hubungan dengan orang lain, TSP merasa takut salah ketika menyampaikan pendapat di depan orang banyak, MRAN merasa bahwa bakatnya tidak sehebat teman-temanya, dan JLR dan APP tidak pernah diberi dukungan dalm belajar oleh orang tua/ keluarga. remaja dengan self esteem rendah tidak dapat memahami dan menerima dirinya. Ia bukan hanya tidak mau melakukan sesuatu hal yang menurut mereka tidak bisa, tetapi juga dalam pikirannya selalu memunculkan informasi yang negatif atau irasional dan perasaan takut untuk mencobanya. Intinya informasi baru tentang dirinya hampir pasti menjadi penyebab kecemasan atau rasa ancaman terhadap dirinya.

Berdasarkan fakta di atas, upaya pencegahan dan pengetasan menjadi agenda yang penting dalam lembaga pendidikan, khususnya untuk para psikolog, konselor dan guru pembimbing. Jika kondisi itu dibiarkan saja tanpa adanya upaya penanganan, maka dapat membahayakan perkembangan di usia remaja, yang dapat mempengaruhi masa depannya kelak. Untuk itu, diperlukan suatu pendekatan konseling yang diperkirakan tepat dalam meningkatkan self esteem siswa, yang menuju pada suatu pembelajaran yang mengarah pada kemampuan berfikir rasional, sehingga ia terhindar dari stress dan depresi dan ia dapat menerima dan menghargai potensi dirinya secara realistis dan dapat menyesuaikan diri dengan lingkungannya. Karena seperti yang kita ketahui, bahwa siswa dengan self esteem yang rendah disebabkan oleh pemikiran-pemikiran yang irasional atau tidak logis.

Menurut Ellis dalam buku Willis, bukan pengalaman atau peristiwa eksternal yang menimbulkan emosional, akan tergantung kepada pengertian yang diberikan terhadap peristiwa atau pengalaman itu. pendapat tersebut pendapat tersebut memaparkan bahwa pemikiran atau pemahaman siswa tentang sesuatu jika dipandang secara irasional, selalu menjadi penyebab kecemasan atau rasa ancaman yang mengakibatkan ganguan emosional pada diri individu.

Dari permasalahan di atas, maka pendekatan konseling yang tepat untuk diberikan adalah pendekatan yang diarahkan pada perubahan pola pikir individu, yang mana hal tersebut dapat meningkatkan self esteem siswa. Untuk itu peneliti menggunakan pendekatan Rational Emotive Behavior Therapy melalui konseling individu karena secara spesifik pendekatan Rational Emotive behavior Therapy menekankan proses berpikir secara rasional sehingga tepat digunakan untuk mengatasi masalah self esteem yang rendah yang bersumber dari pemikiran irasional.

Menurut Ellis Rational Emotive behavior Therapy berusaha membelajarkan kembali konseli untuk memahami input kognitif yang menyebabkan gangguan emosional, mengubah pikiran konseli agar membiarkan pikiran irasionalnya atau belajar mengantisipasi manfaat atau konsekuensi dari tingkah laku. Hal itu menjelaskan bahwa Rational Emotive behavior Therapy dapat mengatasi masalah self esteem (harga diri) yang rendah. Selain itu terdapat pula pertimbangan mengapa teknik ini digunakan yaitu ekonomis dari segi waktu dan dana serta tepat digunakan karena cocok untuk bermacam-macam konseling.

Berdasarkan latar belakang di atas, peneliti ingin mengangkat judul self esteem siswa dengan judul "Meningkatkan Self Esteem dengan Menggunakan Pendekatan Rational Emotive behavior Therapy pada siswa kelas VIII Di SMP Muhammadiyah Lampung Selatan pelajaran 2015/2016.

\section{A. Self Esteem}

Abraham H. Maslow mengemukakan hierarki kebutuhan dari yang paling dasar sampai yang paling tinggi salah satunya adalah kebutuhan penghargaan atau self esteem. Ada beberapa kebutuhan menurut Maslow, yaitu:

1. Kebutuhan fisiologis; 
2. Kebutuhan rasa aman;

3. Kebutuhan rasa memiliki dan rasa kasih sayang;

4. Kebutuhan penghargaan

5. Kebutuhan rasa ingin tahu;

6. Kebuthan estetik;

7. Kebutuhan pertumbuhan; dan

8. Kebutuhan aktualisasi diri.

Self esteem termasuk di dalam kebutuhan penghargaan yang tertera pada nomor empat di atas. Maslow menemukan bahwa setiap orang memiliki dua kategori mengenai kebutuhan penghargaan, yaitu kebutuhan yang dasar dan kebutuhan yang tinggi. Kebutuhan yang dasar adalah kebutuhan untuk menghormati orang lain, kebutuhan akan status, ketenaran, kemulian, pengakuan, reputasi, apresiasi, martabat dan dominasi. Kebutuhan yang tinggi adalah kebutuhan akan harga diri termasuk perasaan, keyakinan, kompetensi, prestasi, penguasaan, kemandirian dan kebebasan. Ketika kebutuhan untuk dihargai sudah terpenuhi, maka mereka sudah siap untuk memasuki gerbang aktualisasi diri, kebutuhan tertinggi yang ditemukan Maslow. Seseorang akan berusaha memenuhi kebutuhan yang lebih tinggi manakala kebutuhan di bawahnya atau kebutuhan yang lebih besar sudah terpenuhi lebih dahulu. Ada dua kategori tentang kebutuhan akan penghargaan pada manusia, yaitu:

a) Kebutuhan harga diri;

b) Kebutuhan akan penghargaan dari orang lain yang meliputi:

1) Kepercayaan diri

2) Kompetensi

3) Penguasaan

4) Kecukupan

5) Prestasi

6) Ketidaktergantungan

7) dan Kebebasan.

Kebutuhan akan harga diri dan penghargaan diri dari orang lain tidak kalah pentingnya dari kebutuhan-kebutuhan lainnya. Harga diri yang paling stabil dan paling sehat adalah yang tumbuh dan berkembang dari penghargaan orang lain yang wajar, bukan penghargaan karena kedudukan, kemasyhuran, atau sanjungan kosong.

\section{Definisi Self Esteem}

Dariyono mengemukakan self esteem ialah suatu kemampuan seseorang untuk dapat melakukan penghargaan terhadap diri sendiri. Deaux mengatakan bahwa self esteem adalah penilaian secara positif dan negatif terhadap diri sendiri. Menurut Wells dan Marwell dalam buku Agus Abdul Rahman mengatakan bahwa self esteem sebagai sikap dan self esteem menunjuk pada suatu objek tertentu yang melibatkan reaksi kognitif, emosi, dan perilaku baik positif maupun negatif. Sedangkan Mruk menyebutkan tiga klasifikasi di dalam mendefinisikan self esteem, yaitu self esteem sebagai suatu kompetensi, self esteem sebagai perasaan berharga, dan self esteem sebagai suatu kompetensi dan perasaan berharga.

Jadi, berdasarkan beberapa pengertian tersebut dapat disimpulkan bahwa self esteem adalah suatu kemampuan individu dalam melakukan penilaian dan penghargaan terhadap diri sendiri yang berupa pemikiran dan perasaan terhadap diri sendiri. Coopersmith mendefinisikan bahwa self esteem merupakan evaluasi yang dibuat individu dan kebiasaan memandang dirinya terutama mengenai sikap menerima atau menolak, dan indikasi besarnya kepercayaan individu terhadap kemampuannya, keberartian, kesuksesan dan keberhargaan. Secara singkat self esteem adalah " personal judgement" mengenai perasaan berharga atau berarti yang 
diekspresikan dalam sikap-sikap individu terhadap dirinya. Berdasarkan teori dari Rosernberg, terdapat tiga dimensi dalam general self esteem yaitu :

\section{a. Performance self esteem}

Dimensi ini merujuk kepada kemampuan individu secara umu meliputi kemampuan intelektual, kepercayaan diri dan efikasi diri. Individu yang memiliki performance self esteem yang tinggi yakin bahwa dirinya pintar dan mampu.

b. Social self esteem

Dimensi ini merujuk pada bagaimana seseorang mempersepsikan dirinya berdasarkan pandangan orang lain. Pada dimensi ini jika individu mempercayai orang lain terutama sesorang yang berarti bagi individu tersebut menghargai dan menerima dirinya, maka individu tersebut dapat memiliki aspek self esteem yang tinggi. Individu yang memiliki social self esteem yang rendah seringkali mengalami kecemasan sosial dan selalu perhatian dengan keadaan dirinya ketika berada di tengah lingkungan, individu tersebut khawatir dengan bagaimana orang lain melihatnya.

c. Physical self esteem

Dimensi ini merujuk bagaimana individu melihat keadaan tubuh mereka, mulai dari kemampuan atletik, ketertarikan fisik, bentuk tubuh dan juga stigma dan pendapat mengenai ras dan etnis.

Jadi, berdasarkan beberapa pengertian di atas dapat disimpulkan bahwa self esteem merupakan personal judgement. Self esteem adalah suatu kemampuan individu dalam melakukan penilaian, penghargaan, dan penerimaan terhadap diri sendiri mengenai baik dan buruknya serta mengenali dan mengembangkan seluruh aspek yang ada pada dirinya. Semakin positif seseorang menilai dirinya maka semakin tinggi self esteemnya, begitu juga sebaliknya semakin negatif seseorang menilai dirinya maka semakin rendah self esteemnya.

2. Sumber self esteem

Banyak ahli yang membahas mengenai self esteem. William James mengungkapkan bahwa self esteem dikembangkan melalui akumulasi dari berbagai pengalaman dimana keberhasilan seseorang melebihi tujuan mereka sebelumnya. Dengan kata lain, self esteem sama dengan keberhasilan atau potensi- potensi yang dimiliki. Cooley berpendapat bahwa self esteem merupakan looking glass self, sehingga penilaian diri dilihat sebagai sesuatu yang tidak dapat dipisahkan dari lingkungan sosial. Sedangkan menurut Mead, self esteem merupakan gambaran dari proses interaksi simbolik (symbolic interactionism), dimana individu menginternalisasikan ide-ide dan perilaku- perilaku yang ditampilkan oleh seseorang yang sangat berpengaruh dalam kehidupannya.

Self esteem yang rendah disebabkan oleh adanya penolakan, diabaikan, dan direndahkan oleh seseorang yang sangat berpengaruh tersebut. Sejalan dengan teori Mead, Coopermith dan Rosernberg mengatakan bahwa penting bagi kita untuk mengukur bagaimana seseorang menilai dirinya melalui bagaimana mereka dilihat oleh orang lain yang berperan penting atau berpengaruh dalam kehidupan mereka, seperti teman sebaya, lingkungan masyarakat, dan anggota keluarga. Sumber self esteem juga dapat berasal dari nilai atau norma-norma budaya dimana individu itu dibesarkan.

Dapat disimpulkan dari beberapa teori di atas bahwa sedikit banyak sumber self esteem berasal dari lingkungan dan perlakuan atau respon yang diterima oleh individu itu sendiri, ketika seseorang berpikir bahwa rendahnya self esteem mendapatkan penguatan maka ia akan cenderung mempertahankan rendahnya self esteem yang dimiliki. Berkaitan dengan masa remaja, hasil penelitian yang dilakukan diberbagai negara menunjukkan bahwa masa yang paling penting dan menentukan perkembangan self esteem seseorang adalah pada masa remaja. Pada masa inilah terutama seseorang akan mengenali dan mengembangkan seluruh 
aspek dalam dirinya sehingga menentukan apakah ia akan memiliki self yang positif dan negatif.

3. Aspek - aspek dan Pondasi Self Esteem

Para ahli psikologi kepribadian, Malhi dalam buku Dariyono, memandang bahwa self esteem seseorang secara umum meliputi tiga aspek yaitu :

a. Harga diri fisik (physically self- esteem, yaitu sikap seseorang untuk dapat menghargai diri sendiri berdasarkan penilaian terhadap karakteristik organ-organ fisiknya.

b. Harga diri prestasi kerja (performance self-esteem), yaitu penghargaan terhadap pengalaman prestasi kerja dimasa lalunya.

c. Harga diri social (social self- esteem)

d. Harga diri fisiologis (physiological self-esteem) ialah sikap seseorang untuk dapat menghargai diri sendiri berdasarkan penilaian terhadap karakteristik organ-organ fisiknya. Harga diri prestasi kerja (performance self-esteem) ialah sikap penghargaan terhadap pengalaman prestasi kerja dimasa lalunya. Harga diri sosial (social self-esteem) ialah sikap penghargaan terhadap penilaian orang lain pada dirinya.

Selain aspek-aspek di atas, self esteem atau penghargaan terhadap diri memiliki tiga pondasi, yaitu :

a. Menerima diri sendiri, yaitu menerima keadaan diri meliputi keadaan fisik dan kemampuan diri.

b. Harga diri, disini seseorang mempunyai harga diri, ia merasa bahwa dirinya adalah bagian penting dari masyarakat, ia mendapatkan penghormatan dari orang lain.

c. Mencintai diri sendiri, yaitu menyukai anugrah yang diberikan oleh ALLAH.

Coopersmith juga menyebutkan terdapat empat aspek dalam self esteem individu, yaitu :

a. Kekuatan atau power menunjuk pada apdanya kemampuan seseorang untuk dapat mengatur dan mengontrol tingkah laku dan mendapat pengakuan atas tingkah laku tersebut dari orang lain.

b. Keberartian atau significance menunjuk kepada kepedulian, perhatian, afeksi dan ekspresi cinta yang diterima oleh seseorang dari orang lain yang menunjukkan adanya penerimaan dan popularitas individu dari lingkungan sosial.

c. Kebajikan atau virtue menunjuk pada adanya suatu ketaatan untuk mengikuti standar moral, etika dan agama.

d. Kemampuan atau competence menunjuk pada adanya performasi yang tinggi untuk memenuhi kebutuhan mencapai prestasi (need of achievement) dimana level dan tugastugas tersebut tergantung pada variasi usia seseorang.

\section{B. Pendekatan Rational Emotive Behavior Therapy}

Dalam penelitian ini, peneliti menggunakan pendekatan rational-emotive behavior Therapy atau yang disingkat REBT yang dikembangi oleh Albert Ellis (seorang ahli Clinical Psychologi atau Psikologi Kinis dalam meningkatkan self esteem atau harga diri siswa.

Pendekatan rational emotive behavior therapy adalah pendekatan behavior kognitif yang menekankan pada keterkaitan antara perasaan, tingkah laku dan pikiran. Secara khusus pendekatan rational emotive behavior therapy berasumsi bahwa individu memiliki karakteristik sebagai berikut :

1. Pikiran irasional berasal dari proses belajar yang irasional yang di dapat dari orang tua dan budayanya; 
2. Manusia adalah makhluk verbal dan berpikir melalui simbol dan bahasa. Dengan demikian, gangguan emosi yang dialami individu disebabkan oleh verbalisasi ide dan pemikiran irasional.

3. Gangguan emosional yang disebabkan oleh verbalisasi diri ( self verbalising) yang terus menerus dan persepsi serta sikap terhadap kejadian merupakan akar permasalahan, bukan karena kejadian itu sendiri.

4. Pikiran dan perasaan yang negatif dan merusak diri dapat diserang dengan menggorganisasikan kembali persepsi dan pemikiran, sehingga menjadi logis dan rasional.

Contoh berpikir tidak logis yang biasanya banyak menguasai individu adalah:

a. Saya harus sempurna.

b. Saya baru saja melakukan kesalahan, bodoh sekali!

c. Ini adalah bukti bahwa saya tidak sempurna, maka saya tidak berguna.

1. Konsep Dasar Rational-Emotive Behavior Therapy

Ellis mengatakan beberapa asumsi dasar REBT yang dapat dikategorisasikan pada beberapa postulat, antara lain:

a. Pikiran, perasaan dan tingkah laku secara berkesinambungan saling berinteraksi dan mempengaruhi satu sama lain;

b. Gangguan emosional disebabkan oleh faktor biologi dan lingkungan;

c. Manusia dipengaruhi oleh orang lain dan lingkungan sekitar;

d. Manusia menyakiti diri sendiri secara kognitif, emosional, dan tingkah laku. Individu sering berpikir yang menyakiti diri sendiri dan orang lain;

e. Ketika hal yang tidak menyenagkan terjadi, individu cenderung menciptakan keyakinan yang irasional tentang kejadian tersebut;

f. Keyakinan irasional menjadi penyebab gangguan kepribadian individu

g. Ketika individu bertingkah laku yang menyakiti diri sendiri( self- defeating behavior).

2. Proses Berpikir Rational Emotive Behavior Therapy

Ellis membagi pikiran individu dalam tiga tingkatan, yaitu: dingin ( $\mathrm{cool})$, hangat (warm), dan panas (hot), yang mengilustrasikan bagaimana emosi terintegrasi dalam pikiran. Pikiran dingin (cool) adalah pikiran yang bersifat deskriptif dan mengandung sedikit emosi, sedangkan pikiran yang hangat (warm) adalah pikiran yang mengarah pada satu preferensi atau keyakinan rasional, pikiran ini mengandung unsur evaluasi yang mempengaruhi pembetukan perasaan. Adapun pikiran yang panas (hot) adalah pikiran yang mengandung unsur evaluasi yang tinggi dan penuh dengan perasaan (Nelson Jones

\section{Tujuan Rational Emotive Behavior Therapy}

Tujuan utama konseling dengan pendekatan rational-emotive behavior therapy adalah membantu individu menyadari bahwa mereka dapat hidup dengan lebih rasional dan lebih produktif. Secara lebih gamblang, rational emotive behavior therapy (REBT) mengajarkan individu untuk mengoreksi kesalahan berpikir untuk mereduksi emosi yang tidak diharapkan. Selain itu, (REBT) membantu individu untuk mengubah kebiasaan berpikir dan tingkah laku yang merusak diri. Secara umum, (REBT) mendukung konseling untuk menjadi lebih toleran terhadap diri sendiri, orang lain, dan lingkungannya.

Ellis dan Benard mendeskripsikan beberapa sub tujuan pendekatan REBT yang dapat membantu individu mencapai nilai untuk hidup dan untuk menikmati hidup. Tujuan tersebut adalah :

a. Memiliki minat diri (self interest); 

b. Memiliki minat sosial (social interest);
c. Memiliki pengarahan diri (self direction);
d. Toleransi (tolerance);
e. Fleksibel (Flexibility);
f. Memiliki penerimaan (acceptance);
g. Dapat menerima ketidakpastian;
h. Dapat menerima diri sendiri;
i. Dapat mengambil resiko;
j. Memiliki harapan yang realitis;
k. Memiliki toleransi terhadap frustasi yang tinggi; dan
1. Memiliki tanggung jawab pribadi.

Berdasarkan uraian di atas dapat disimpulkan bahwa tujuan utama dari rationalemotive behavior therapy ialah menunjukkan dan menyadarkan klien bahwa cara berpikir yang tidak logis itulah merupakan penyebab gangguan emosionalnya, atau dengan kata lain konseling rational- behavior therapy ini bertujuan untuk membantu klien membebaskan dirinya dari cara berpikir atau ide-idenya yang tidak logis dan menggantikannya dengan caracara yang logis. Siswa yang mempunyai self esteem atau penilaian tentang diri yang negatif, dikarenakan ia terpengaruh oleh cara berpikir yang irrasional. Oleh karena itu melalui konseling rational-emotive behavior therapy diharapkan dapat merubah cara berpikir siswa kelas VIII di SMP Muhammadiyah Jati Agung Lampung Selatan tahun Ajaran

2015/2016.

C. Keterkaitan Rational Emotive Behavior Therapy dalam Meningkatkan Self esteem.

Rational emotive behavior therapy adalah aliran psikoterapi yang mengungkapkan bahwa manusia pada dasarnya dilahirkan dengan potensi untuk berfikir rasional dan irasional. Seseorang yang mengalami gangguan psikologis atau gangguan emosional berasal dari keyakinan, dan cara berpikir yang irasional terhadap suatu pengalaman atau peristiwa dalam hidupnya.

Ellis mengatakan bahwa bukan pengalaman atau peristiwa eksternal yang menimbulkan emosional, akan tetapi tergantung kepada pengertian yang diberikan terhadap peristiwa itu. Pendapat itu memperjelas bahwa pemikiran yang irasional dapat memunculkan gangguan emosional. Untuk itu, melalui konseling rational-emotive behavior therapy terapis berupaya untuk mengarahkan konseli kepada pemikiran yang rasional atau logis.

Siswa dengan self esteem atau penilaian diri yang tinggi akan memandang positif akan sesuatu hal yang terjadi. Ia dapat memahami dan menerima dirinya apa adanya, dapat menyerap semua informasi tentang dirinya dan tak satupun dari informasi tersebut yang menjadi ancaman bagi dirinya. Sebaliknya, siswa dengan self esteem rendah tidak dapat memahami dan menerima dirinya. Ia bukan hanya tidak mau melakukan sesuatu hal yang menurut mereka tidak bisa, tetapi juga dalam pikirannya selalu memunculkan informasi yang negatif atau irasional dan perasaan takut untuk mencobanya. Intinya informasi baru tentang dirinya hampir pasti menjadi penyebab kecemasan atau rasa ancaman terhadap dirinya.

Siswa yang mempunyai self esteem yang rendah akan memunculkan sikap penolakan diri, kurang puas terhadap diri, merasa rendah diri, merasa dirinya tidak mampu dan tidak berharga, tidak berani mencari tantangan baru dalam hidupnya, tidak merasa orang lain, tidak mampu membina komunikasi yang baik dan cenderung merasa hidupnya tidak bahagia. Perasaan-perasaan yang bersumber dari pikiran yang negatif tersebut, yang kemudian diyakini ke dalam hatinya lalu terwujudlah tingkah laku atau respon yang negatif.

Untuk itu, penggunaan pada konseling rational emotive behavior therapy sangat tepat dalam mengatasi masalah self esteem yang rendah. Siswa dengan self esteem rendah dapat 
diberikan konseling rational emotive behavior therapy agar pemikiran-pemikiran yang irasional yang memunculkan penilaian negatif tentang dirinya dapat hilang dan diubah dengan pemikiran-pemikiran rasional sehingga dapat memunculkan penilaian yang positif terhadap dirinya dan otomatis self esteemnya meningkat.

Ellis mengatakan bahwa Terapis rational emotive behavior therapy berusaha membantu mereka untuk mengatasi segenap manifestasi dari depresi, kesakitan, kehilangan rasa berharga dan kebencian. Oleh karena itu melalui konseling rational emotive behavior therapy diharapkan dapat merubah cara berfikir siswa kelas VIII di SMP Muhammadiyah Lampung Selatan Tahun ajaran 2015/2016 mengenai keadaan dirinya sendiri.

\section{Metode Penelitian}

Dalam penelitian ini mengunakan metode penelitian kuantitatif dengan Jenis penelitian yang peneliti gunakan adalah penelitian eksperiment. Menurut Sugiono penelitian eksperiment didefinisikan sebagai metode penelitian yang digunakan untuk mencari pengaruh perlakuan tertentu terhadap yang lain dalam kondisi yang terkendalikan. Alasan peneliti menggunakan jenis penelitian ini, karena penelitian ini menggunakan perlakuan (trentment) yang dilakukan oleh peneliti.

\section{Hasil dan Pembahasan}

Hasil penelitian pada dasarnya memuat berbagai hal meliputi pengungkapan data dari instrumen penelitian dan metode analisis data yang diperoleh untuk menjawab permasalahan yang diajukan.

1. Gambaran Umum Pra Konseling

Pelaksanaan penelitian peningkatan self esteem dengan menggunakan pendekatan rational emotive behavior therapy dilaksanakan di SMP Muhammadiyah Jati Agung Lampung Selatan tahun ajaran 2015/2018. sebelum dilakasanakan proses konseling rational emotive behavior therapy, tahap pertama yang dilakukan peneliti untuk mengetahui self esteem siswa yang rendah adalah melakukan wawancara kepada guru bimbingan konseling (BK). Dari hasil wawancara tersebut guru BK merekomedasikan 31 siswa yang tersebar di kelas VIII yang diketahui memiliki self esteem yang rendah.

Setelah mengetahui siswa yang mengalami self esteem rendah, selanjutnya peneliti menyebarkan angket self esteem kepada 31 siswa. Dari hasil analisis angket didapatlah 12 siswa yang memiliki self esteem rendah. Keduabelas siswa itulah yang akan diberikan layanan konseling individual dengan pendekatan rational emotive behavior therapy. Peneliti menjelaskan tata cara dalam pelaksanaan layanan individual.

Kemudian membuat kesepakatan untuk melakukan konseling dan menetapkan hari dan waktu pelaksanaan konseling kepada keduabelas siswa sebagai subjek penelitian. Setelah dilakukan konseling dengan pendekatan rational emotive behavior therapy pada masing-masing subjek penelitian sebanyak 3-4 kali pertemuan, maka penelitian membagikan kembali angket yang sama yaitu angket self esteem kapada 12 siswa tersebut. Setelah dilakukan analisis, maka diperoleh hasil yang memuaskan, karena tujuan dari konseling yang diinginkan dapat tercapai yaitu terjadi peningkatan self esteem kepada keduabelas siswa.

2. Deskripsi Data Pre-Test

Data yang diperoleh untuk mengetahui hasil pretest dan posttest diperoleh dari pengisian angket self esteem. Pretest merupakan penelitian yang dilakukan peneliti sebelum penelti menyelenggarakan kegiatan konseling individual dengan pendekatan rational emotive behavior therapy. Setelah diperoleh pretest, siswa yang memperoleh skor self esteem yang rendah dapat dilihat pada tabel 4.1 Berikut ini. 
Tabel 4.1 Hasil Pretest Skala Self Esteem

\begin{tabular}{cccc}
\hline No & Nama & Skor & Kriteria \\
\hline 1 & RES & 42 & Rendah \\
\hline 2 & MF & 42 & Rendah \\
\hline 3 & BNS & 42 & Rendah \\
\hline 4 & SP & 43 & Rendah \\
\hline 5 & SW & 44 & Rendah \\
\hline 6 & TSP & 46 & Rendah \\
\hline 7 & MRAN & 44 & Rendah \\
\hline 8 & JLR & 43 & Rendah \\
\hline 9 & AAP & 42 & Rendah \\
\hline 10 & PR & 41 & Rendah \\
\hline 11 & GDN & 46 & Rendah \\
\hline 12 & RMP & 43 & Rendah \\
\hline
\end{tabular}

Tabel menyatakan gambaran dari peserta didik kelas VIII yang teridentifikasi self esteem rendah.tujuan diadakannya layanan konseling individu dengan pendekatan rational emotive behavior therapy agar dapat meningkatkan self esteem peserta didik kelas VIII di SMP Muhammadiyah Jati Agung.

\section{Deskripsi Data Posttest}

Posttest digunakan untuk mengetahui kondisi masing-masing individu setelah diberikan treatment. Data hasil posttest duabelas siswa yang telah diberikan treatment rational emotive behavior therapy dapat dilihat pada tabel 4.2 berikut:

Tabel 4.2 Hasil Posttest Skala Self Esteem

\begin{tabular}{cccc}
\hline No & Nama & Skor & Kriteria \\
\hline 1 & RES & 75 & Tinggi \\
\hline 2 & MF & 79 & Tinggi \\
\hline 3 & BNS & 76 & Tinggi \\
\hline 4 & SP & 75 & Tinggi \\
\hline 5 & SW & 78 & Tinggi \\
\hline 6 & TSP & 77 & Tinggi \\
\hline 7 & MRAN & 76 & Tinggi \\
\hline 8 & JLR & 76 & Tinggi \\
\hline 9 & AAP & 74 & Tinggi \\
\hline 10 & PR & 76 & Tinggi \\
\hline 11 & GDN & 78 & Tinggi \\
\hline 12 & RMP & 77 & Tinggi \\
\hline
\end{tabular}

Dilihat dari tabel 4.2. diketahui terjadi peningkatan self esteem dibandindingkan dengan hasil pretest pada tabel 4.2. yaitu keduabelas peserta didik yang memiliki self esteem rendah meningakat menjadi tinggi. Pelaksanaan posttest dilakukan setelah pelaksanaan pendekatan rational emotive behavior therapy. Berikut ini hasil penghitungan skala sebelum (pretest) dan setelah pemberian (posttest) pendekatan rational emotive behavior therapy. 
Tabel 4.3 Uji Hasil Preetest dan Posttest Skala Self Esteem

\begin{tabular}{|c|c|c|c|c|}
\hline \multirow{2}{*}{ No } & \multirow{2}{*}{ Nama } & \multicolumn{2}{|c|}{ Potensi } & \multirow{2}{*}{ Total } \\
\hline & & Pretest & Postest & \\
\hline 1 & RES & 42 & 75 & 33 \\
\hline 2 & $\mathrm{MF}$ & 42 & 79 & 37 \\
\hline 3 & BNS & 42 & 76 & 34 \\
\hline 4 & SP & 43 & 75 & 32 \\
\hline 5 & SW & 44 & 78 & 34 \\
\hline 6 & TSP & 46 & 77 & 31 \\
\hline 7 & MRAN & 44 & 76 & 32 \\
\hline 8 & JLR & 43 & 76 & 33 \\
\hline 9 & $\mathrm{AAP}$ & 42 & 74 & 32 \\
\hline 10 & PR & 41 & 76 & 35 \\
\hline 11 & GDN & 46 & 78 & 32 \\
\hline 12 & RMP & 43 & 77 & 34 \\
\hline \multirow{2}{*}{\multicolumn{2}{|c|}{$\mathrm{N}=12$}} & $\sum=$ & 917 & \\
\hline & & $\begin{array}{l}X 1 \\
=518 \\
/ 12\end{array}$ & $\begin{array}{l}\text { X2 } \\
=917 / 12\end{array}$ & $\mathbf{M d}=\sum \mathbf{d} / \mathbf{N}$ \\
\hline \multicolumn{2}{|c|}{ Rata-rata } & 43,16 & 76,41 & 33,25 \\
\hline
\end{tabular}

Dari tabel 4.3. dapat dilihat bahwa hasil pretest terhadap 12 subjek sebelum pemberian diperoleh nilai rata-rata skor self esteem sebesar 43,16. Setelah dilakukakn pendekatan rational emotive behavior, hasil posttest diperoleh nilai rata-rata 76,41, yang berarti terjadi peningkatan skor sebesar 33,25.. Hal ini menunjukan bahwa terdapat peningkatan self esteem peserta didik sebelum diberi pendekatan rational emotive behavior therapy dengan setelah diberi pendekatan rational emotive behavior therapy. Grafik peningkatan self esteem peserta didik yang dioeroleh dari hasil skor nilai pretest dan posttest setiap siswa dapat dilihat sebagai berikut:

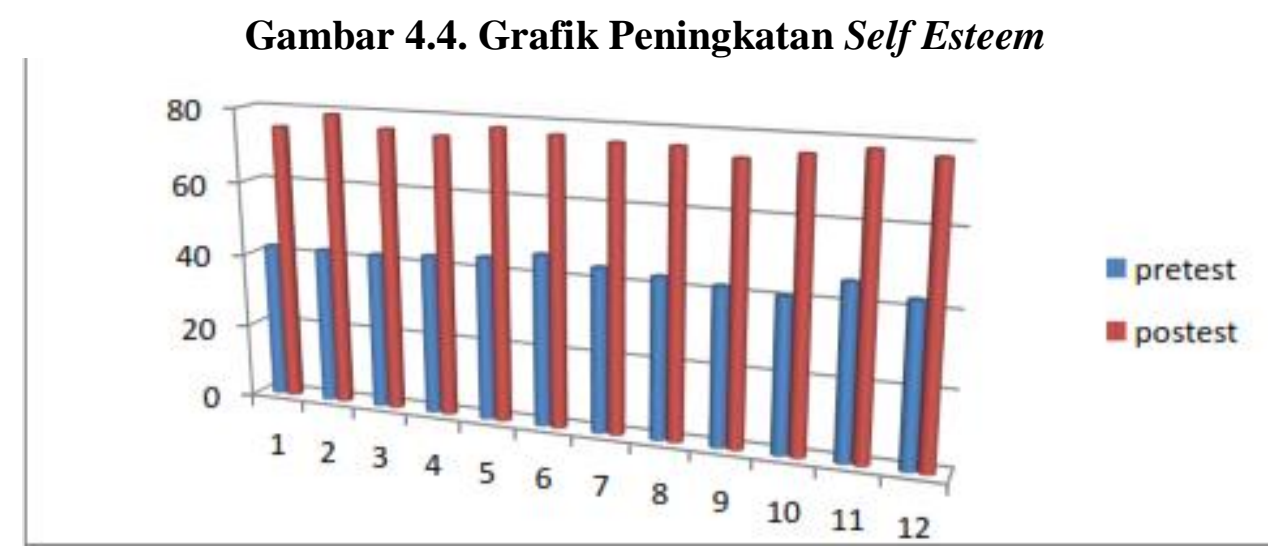

Dapat dilihat pada gambar 4.4 bahwa terjadi peningkatan skor self esteem ketika sesudah diberiksn treatmen konseling individual pendekatan rational emotive behavior therapy. Dalam penghitungan stastistik (mean median modus) dengan menggunakan program SPSS 16 adalah sebagai berikut: 
Tabel 4.5 Hasil Nilai Stastistik Self Esteem

\begin{tabular}{lrrr}
\hline & & pretest & Postest \\
\hline $\mathrm{N}$ & Valid & 12 & 12 \\
\cline { 2 - 4 } & Missing & 0 & 0 \\
\hline Mean & 431.667 & 764.167 \\
\hline Median & 430.000 & 760.000 \\
\hline Mode & 42.00 & 76. \\
\hline Sum & 518.0 & 917.0 \\
\hline
\end{tabular}

\section{Uji Hipotesis}

Hipotesis dalam penelitian ini adalah :

$\mathrm{H}_{\mathrm{O}}$ : self esteem peserta didik tidak dapat ditingkatkan menggunakan pendekatan rational emotive behavior therapy.

$\mathrm{H}_{\mathrm{a}}$ : self esteem peserta didik dapat ditingkatkan menggunakan pendekatan rational emotive behavior therapy.

Adapun hipotesis statistiknya adalah sebagai berikut:

HO : zhitung > ztabel

$\mathrm{Ha}$ : zhitung < ztabel

Tabel 4.6 Hasil Uji Wilcoxon

\begin{tabular}{cc}
\hline & postest - pretest \\
\hline $\mathrm{Z}$ & $-3.077 \mathrm{a}$ \\
\hline $\begin{array}{c}\text { Asymp. Sig } \\
\text { (2- tailed) }\end{array}$ & .002
\end{tabular}

Berdasarkan uji wilcoxon dalam tabel 4.5, diperoleh nilai Asymp.Sig. (2-tailed) sebesar 0.002 karena nilai sig $0.002<0.005$, dengan perhitungan pengujian wilcoxon diperoleh Zhitung -3.007 dan Ztabel 0.05=0.0011, maka Zhitung > Ztabel (-3.007 > 0.0011) dengan nilai sign (2- tailed) dengan demikian berdasarkan uji wilcoxon dapat disimpulkan Ho ditolak Ha diterima, jadi dapat disimpulkan bahwa self esteem yang rendah dapat ditingkatkan dengan menggunakan pendekatan Rational Emotive Behavior Therapy.

Pembahasan hasil penelitian diawali dengan profil self esteem, dilanjutkan dengan menganalisis program yang tepat. Adapun pembahasan upaya meningkatkan self esteem menggunakan pendekatan rational emotive behavior therapy adalah sebagi berikut :

1. Gambaran Umum Self Esteem Peserta Didik Kelas VIII SMP Muhammadiyah Jati Agung.

Berdasarkan hasil penelitian yang telah dilakukan menunjukkan bahwa self esteem peserta didik kelas VIII SMP Muhammadiyah Jati Agung tahun ajaran 2015/2016 sebagian besar berada dalam kategori tinggi, namun masih terdapat peserta didik yang berada dalam kategori rendah. Sehingga apabila dibiarkan maka dapat menghambat proses berinteraksi sosial dalam kehidupan sehari-hari dan dalam proses belajar mengajar.

Pada penelitian ini terfokus pada self esteem dalam berinteraksi sosial. Peserta didik memiliki self esteem yang tinggi/ positif diharapkan dapat mempermudah peserta didik dalam kehidupan sehari-hari termasuk dalam proses belajar mengajar.

Self esteem mempunyai pengaruh yang kuat terhadap perilaku yang ditampilkanya. Self esteem merupakan pengatur utama perilaku individu atau merupakan pemimpin bagi semua dorongan. Untuk itu self esteem perlu diterapkan oleh setiap individu. 
Menurut Coopersmith mendefinisikanself esteem merupakan evaluasi yang dibuat individu dan kebiasaan memandang dirinya terutama mengenai sikap menerima dan menolak, dan indikasi besarnya kepercayaan individu terhadap kemampuannya, keberartian, kesuksesan dan keberhargaan. Secara singkat self esteem adalah "personal judgement" mengenai perasaan berharga atau berarti yang diekspresikan dalam sikap-sikap individu terhadap dirinya

Oleh karena itu, dalam penelitian ini peneliti membantu peserta didik meningkatkan self esteem peserta didik yang berada pada kategori rendah dengan menggunakan pendekatan rational emotive behavior therapy, agar peserta didik dapat memiliki self esteem tinggi yang akan berpengaruh pada kehidupan sehari-hari. Self esteem dapat ditingkatkan dengan mengajarkan kepada peserta didik untuk bersikap tegas kepada orang-orang yang berusaha menindas dengan menghina atau merendahkan. Bedasarkan wawancara kepada peserta didik sebagaian besar faktor yang mempengaruhi self esteem peserta didik yaitu penerimaaan teman sebaya terhadap keberadaanya. Hal ini sesuai dengan pendapat Harter Oosterwegel dan Oppenheimer yang menyatakan bahwa " dukungan teman sebaya (peer) adalah faktor lain yang tidak kalah penting dibanding faktor lainnya".

Secara umum, remaja yang mendapatkan penerimaan dan dukungan dari peer memiliki self esteem yang tinggi dan lebih sedikit memiliki masalah emosional seperti perasaan keterasingan dan prestasi sekolah yang baik. Selain faktor teman sebaya, terdapat faktor lain yang mempengaruhi self esteem yaitu gender, ras, status sosial, dan peran orang tua.

Dalam penelitian ini, peneliti menggunakan layanan konseling pendekatan rational emotive behavior therapy dalam meningkatkan self esteem keduabelas subjek penelitian. Pendekatan ini tepat digunakan karena secara spesifik rational emotive behavior therapy menekankan bahwa tingkah laku yang bermasalah disebabkan oleh pemikiran yang irasional sehingga tepat untuk digunakan untuk mengatasi masalah self esteem yang rendah bersumber dari pemikiran irasional. Sebagaimana tujuan rational emotive behavior therapy adalah membantu individu menyadari bahwa meraka dapat hidup lebih rasional dan lebih produktif.

Bagaimana seseorang menilai tentang dirinya baik positif atau negatif akan mempengaruhi tingkah lakunya. Semakin positif seseoarang menilai dirinya maka semakin tinggi self esteemnya, begitu juga sebaliknya semakin negatif seseorang memandang dirinya maka semakin semakin rendah self esteemnya. Permasalahan yang dialami oleh kedua belas subjek penelitian hampir semua berasal dari dalam diri mereka sendiri. Mereka cenderung terlalu cepat berpikir dan menilai secara irasional akan dirinya ataupun orang lain, bahkan meyakini persepsi yang belum tentu kebenarannya. Dan disitulah muncul gangguan emosional yang nantinya akan mempengaruhi dalam hubungan dengan orang lain.

Dalam penelitian ini, peneliti menggunakan layanan konseling pendekatan rational emotive behavior therapy dalam meningkatkan self esteem kedua belas subjek penelitian. Dalam melaksanakan konseling rational emotive beahvior therapy, ada beberapa teknik yang dapat dipakai. Beberapa teknik dalam konseling rational emotive behavior therapy dapat dikategorikan menjadi 3 kelompok yaitu:
a. Teknik kogniktif
b. Teknik imageri
c. Teknik behavioral

Dari berbagai teknik di atas yang digunakan oleh peneliti adalah teknik kognitif dan teknik behavioral. 


\section{Simpulan dan Saran}

Berdasarkan hasil perhitungan rata-rata skor self esteem peserta didik sebelum mengikuti layanan konseling individual dengan pendekatan rational emotive behavior therapy adalah 43,16, setelah diberikan layanan konseling individual melalui pendekatan rational emotive behavior therapy terjadi peningkatan skor menjadi 76,41. Dari hasil (Uji wilcoxon) diperoleh Zhitung - 3.007 dan Ztabel 0.05=0.0011, maka Zhitung > Ztabel (-3.007 $>0.0011)$. Dengan demikian self esteem peserta didik terdapat perubahan setelah diberikan pendekatan rational emotive behavior therapy. jadi hal ini menunjukkan bahwa Ho ditolak Ha diterima, maka dapat disimpulkan bahwa layanan konseling individual menggunakan pendekatan rational emotive behavior therapy dapat meningkatkan self esteem peserta didik kelas VIII, Hal ini dapat dilihat dari perbedaan dan perbandingan antara hasil pretest dan posttest.

Berdasarkan hasil pembahasan, penelitian memberi saran-saran sebagai berikut :

1. Kepada guru bimbingan dan konseling Guru bimbingan dan koseling agar dapat memprogramkan dan melaksanakan pendekatan rational emotive behavior therapy dengan layanan konseling individual secara optimal agar dapat membantu meningkatan self esteem peserta didik.

2. Kepada peserta didik Agar bisa mencintai diri sendiri apapun keadaanya dan apabila mengalami perasaan kurang berharga hendaknya menemui guru bimbingan konseling untuk mendapatkan layanan konseling.

\section{Daftar Pustaka}

Al Qur'an dan Terjemahnya (revisi terbaru D.A RI, Semarang, CV. Asy Syifa) QS. Al-Fajr ayat 27:30.

Albert Ellis 2014, The Empirical Status Of Rational Emotif Behavior Therapy (Rebt) Theory \& Practice Albert Ellis Institute New York, Tersedia Jurnal

Aqib Zainal, 2013. Konseling Kesehatan Mental, Bandung: CV Yrama Widya. Dewa Ketut Sukardi, 2008. Pengantar Pelaksanaan Program Bimbingan dan Konseling di Sekolah, Jakarta, PT. Rineka Cipta.

Friedman.S.Howard \& Schustack. W.Miriam, 2008. Kepribadian Teori Klasik dan Riset Modern, Jakarta: Erlangga.

Gantina Komalasari \& dkk, 2011. Teori dan Teknik Konseling, (Jakarta Barat, PT Indeks,).

Hadi Sutrisno, 1988. Metodologi Research, (Yogyakarta, Andi Offset, Jayanti Tri, 2012,

Kartono Kartini, 2004. Kamus Lengkap Psikologi, Jakarta: Raja Grafindo Persada.

Khairani Makmun, 2014. Psikologi Konseling. Yogyakarta, CV.Aswaja Persindo.

Margono.S, Metodologi Penelitian Pendidikan, 2010. Jakarta: PT Rineka Cipta.

Muhibbin Syah, 2012. Psikologi Belajar, Jakarta: Rajawali Pers.

Nani Wulandari, Guru BK SMP Gajah Mada Bandar Lampung.

Nevid.S.Jefrfrey, dkk, 2003. Psikologi Abnormal, Jakarta: Erlangga

Mengurangi Perilaku Siswa tidak Tegas Melalui Pendekatan REBT dengan Teknik Assertive Training Univ. Negeri Semarang, (Online) Jurnal (http://journal.unnes.ac.idartikel_sjuj bk309358.pdf diakses pada pukul 19.20 WIB 28 Januari 2016. 
(http://albertellis.orgpdf_filesThe-Empirical-Status-of-Rational-Emotive-Behavior-Theoryand- Therapy.pdf diakses pada pukul 09.30 WIB 31 Januari 2016. 